引用格式: 董光龙,许尔琪, 张红旗. 黄淮海平原不同类型农村居民点空间分布及变化特征研究 $[\mathrm{J}]$. 资源科学, 2017,39(7): 1248-1258. [Dong G L, Xu E Q, Zhang H Q. The spatial distribution and evolution of different types of rural settlements on HuangHuai-Hai Plain[J]. Resources Science, 2017,39(7) : 1248-1258.] DOI: 10.18402/resci.2017.07.03

\title{
黄淮海平原不同类型农村居民点空间分布 及变化特征研究
}

\author{
董光龙 ${ }^{1,2}$, 许尔琪 ${ }^{1}$, 张红旗 ${ }^{1}$ \\ (1. 中国科学院地理科学与资源研究所, 陆地表层格局与模拟重点实验室, 北京 100101 ; \\ 2. 中国科学院大学, 北京 100049)
}

\begin{abstract}
摘 要:科学划分农村居民点类型,深入挖掘不同类型农村居民点的差异性,是农村居民点差异化管控的基 础, 有助于乡村转型发展和新型城镇化建设。本文以黄淮海平原为例, 基于遥感解译获取了农村居民点空间数据, 采用空间叠加的方法,从农村居民点的规模、形态和分布三个方面划分了 2015 年农村居民点的类型, 并进一步分析 了不同规模、形态和分布组合下农村居民点集约利用水平、用地变化等的差异性。结果表明: 1)2015年黄淮海平原 农村居民点可划分为 12 种类型, 并以小斑块较规整高密度、小斑块较规整中密度和中斑块不规整低密度三种类型 为主。(2)相比于黄河以南地区, 黄淮海平原黄河以北的县域内农村居民点斑块规模较大、密度较低。(3)农村居民 点的规模和密度对人均农村居民点面积的影响较大。在小而密集的分布状态下,农村居民点用地较为粗放; 在大 而疏的分布状态下, 农村居民点用地较为集约。(4.农村居民点数量增加较多的县域, 多为小斑块类型; 而农村居民 点数量呈减少趋势的县域, 多为中大斑块与中低密度的组合类型。5 农村居民点的规模和形状与农村居民点面积 变化之间的关系较为密切; 形状不规整和小斑块组合类型的农村居民点面积增加较为显著, 而形状较规整和小斑 块组合类型的农村居民点是面积减少的主体。
\end{abstract}

关键词:农村居民点;空间布局; 时空变化; 类型;黄淮海平原

DOI: $10.18402 /$ resci.2017.07.03

\section{1 引言}

农村居民点是农村居民生产和生活的载体, 其 形态和空间分布格局等是人地关系的综合反映。 中国地域辽阔,各地区的历史发展过程、自然条件、 社会经济发展水平、生活习惯、风俗文化等差异较 大。受此影响,农村居民点的规模、形态、分布、结 构、功能等呈现出显著的区域差异性 ${ }^{[-3]}$ 。

不同类型农村居民点的规模、形态和分布等特 征及其差异性研究, 是因地制宜进行农村居民点管 控的基础。为此,部分学者对黄河三角洲 ${ }^{[4]}$ 、平原 粮食主产区 ${ }^{[5]}$ 、黄土丘陵区 ${ }^{[0]}$ 、山区 ${ }^{[7]}$ 、发达地区 ${ }^{[8]}$ 、都 市郊区 ${ }^{[9,100}$ 等典型地区的农村居民点空间分布格局
进行了相关分析。

还有些学者则进一步划分了农村居民点的类 型。早期以林超先生为代表,所进行的农村居民点 分类主要以经验分析方法为主 ${ }^{[11]}$ 。近年来,农村居 民点分类研究呈现出定性分析和定量刻画多元化 发展的趋势。定性分析主要是对农村居民点形状、 分布等性状的描述。如马少春根据农村居民点的 形态将环洱海地区农村居民点分为块状、带状和不 规则状等类型 ${ }^{[12]}$; 谭雪兰根据农村居民点的分布将 其分为集聚性、卫星型、带状型和自由型 ${ }^{[13]}$; 还可以 根据农村居民点的区位将其分为沿路分布型和沿 河分布型等。定量研究则是基于农村居民点本身

收稿日期: 2016-12-05; 修订日期: 2017-05-04

基金项目:中国工程院重大咨询项目课题(2014-05-ZD-001)。

作者简介: 董光龙,男,山东日照人,博士生,研究方向为土地信息技术及其应用。E-mail : donggl.13b@igsnrr.ac.cn

通讯作者: 张红旗,E-mail : zhanghq@igsnrr.ac.cn

http://www.resci.cn 
的一些性状及其相关影响因素,通过构建分类指标 体系或采取某种方法进行类型划分。所采用的分 类方法主要包括单指标评价法、综合评价法、聚类 法、空间自相关法和矩阵组合法等。龙花楼等根据 一、二、三产业产值占总产值的比重将农村居民点 划分为农业主导型、工业主导型、第三产业主导型 和均衡发展型 ${ }^{[14]}$; 乔陆印等采用综合指标法划分了 中国农村居民点用地变化类型 ${ }^{[15]}$; Song 等采用层次 聚类法, 以省域为评价单元, 进行了中国农村居民 点分区 ${ }^{[16]}$;马晓冬等采用系统聚类法, 在县级尺度上 将江苏省农村居民点划分为 8 种类型 ${ }^{[1]}$; 姜广辉等基 于农村居民点的形态差异,利用空间自相关法对北 京市平谷区农村居民点进行分区 ${ }^{[17]}$; 张瑞娟等采用 组合矩阵法, 从规模、形态和区位三个维度对北京 市平谷区农村居民点类型进行了划分 ${ }^{[18]}$ 。

以上研究对农村居民点类型的科学表征和分 类研究做出了有益推进,为农村居民点的区域差异 化管理提供了科学参考。但仍存在一些不足之处： (1)在分类方法上以聚类分析和综合评价法为主,但 具有一定的主观性并容易掩盖农村居民点在单个 维度上的特征 ${ }^{[18]}$; (2)大部分农村居民点分类研究是 一种静态研究,忽视了农村居民点用地是一个动态 变化的过程,对于不同类型农村居民点变化的差异 性分析不足。

鉴于此,本文利用遥感解译获取的农村居民点 数据,采用空间叠加的方法划分农村居民点类型, 比较分析不同类型农村居民点的差异性,重点关注 并拟解决以下问题:不同的规模、形态和布局等组 合状态下人均农村居民点用地差异如何? 农村居 民点用地扩张主要发生在哪些类型? 以期为相关 研究提供一些启发和参考, 为乡村转型发展和新型 城镇化建设等提供科学依据。

\section{2 研究区与数据来源}

\section{1 研究区概况}

确定本文中黄淮海平原的空间范围时,首先依 据 $1 \mathrm{~km}$ 分辨率的 DEM 数据和县级行政区划数据初 步粗略划定大体范围。然后考虑到本文的主要目 的是分析平原地区农村居民点的类型及其差异性， 进一步参考 $30 \mathrm{~m}$ 分辨率的遥感影像将位于黄淮海 平原边缘且山区面积占比较大的县域剔除,得到最
终的黄淮海平原空间分布范围 (图 1)。大致介于 $\mathrm{N} 32^{\circ} 16^{\prime} 50^{\prime \prime}-\mathrm{N} 40^{\circ} 5^{\prime} 18^{\prime \prime}$ 和 E $112^{\circ} 33^{\prime} 43^{\prime \prime}-\mathrm{E} 119^{\circ} 52^{\prime} 21^{\prime \prime}$ 之间, 涉及京、津、冀、鲁、豫、皖和苏等 7 个省市, 覆 盖 240 个县级行政区划单元 (表 1), 总面积约为 26 万 $\mathrm{km}^{2}$ 。黄淮海平原地势平坦、土地资源肥沃、气候 条件适宜,农作物生产潜力巨大, 是中国重要的粮 食生产基地。凭借得天独厚的自然条件、靠近海岸 线等区位优势,这里城镇村密集分布, 是中国人口 密集区。相比其他地区, 黄淮海平原农村居民点的 密度和扩张速率均较高 ${ }^{[3,19]}$ 。2014 年末黄淮海平原 总人口数为 4.43 亿人, 其中农村人口共 2.24 亿人, 占黄淮海平原总人口的 $50.46 \%$ 。农民人均纯收人 为 12010.19 元, 高于全国平均水平 (9892.00元)。

\section{2 数据来源}

Zhu等的研究发现改革开放(1978年)之前,农 村居民点是农业经济时期的终极形态, 其规模、区 位长期处于相对稳定状态 ${ }^{[2]}$; 改革开放之后,中国社 会经济得到了快速发展,尤其是 1990 年以来,农民 人均纯收人得到了显著提高,在改善住房条件等的 刺激下,农村居民点的规模和布局产生了较大变化 ${ }^{[19]}$ 因此,结合到数据的可获取性和时效性, 本文尝试

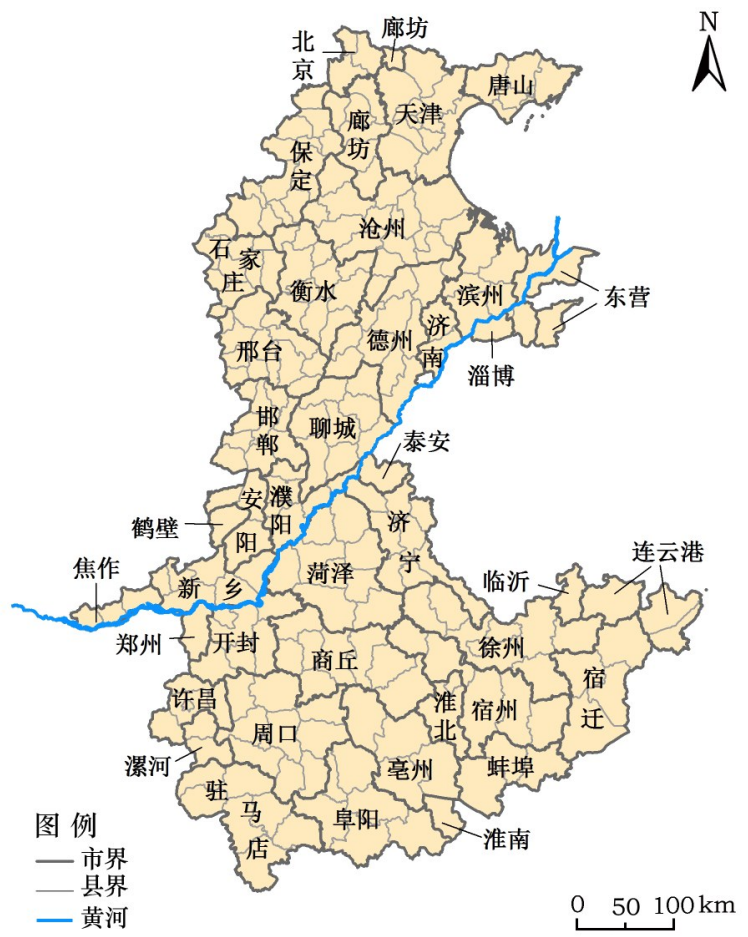

图 1 黄淮海平原位置

Figure 1 Location of Huang-Huai-Hai Plain 
表 1 黄淮海平原所涉及县域在各省市中的数量

Table 1 The numbers of the counties of Huang-Huai-Hai Plain within each province and city

\begin{tabular}{|c|c|c|c|}
\hline 省市 & 县域数量 & 省市 & 县域数量 \\
\hline 北京市 & 3 & 河南省 & 58 \\
\hline 天津市 & 10 & 安阳市 & 3 \\
\hline 安徽省 & 21 & 鹤壁市 & 1 \\
\hline 蛙埠市 & 3 & 焦作市 & 3 \\
\hline 毫州市 & 4 & 开封市 & 6 \\
\hline 阜阳市 & 6 & 漯河市 & 2 \\
\hline 淮北市 & 2 & 兴阳市 & 6 \\
\hline 淮南市 & 1 & 商丘市 & 8 \\
\hline 宿州市 & 5 & 新乡市 & 6 \\
\hline 河北省 & 84 & 许昌市 & 5 \\
\hline 保定市 & 14 & 郑州市 & 1 \\
\hline 沧州市 & 15 & 周口市 & 10 \\
\hline 邯䣋市 & 10 & 驻马店市 & 7 \\
\hline 衡水市 & 11 & 山东省 & 50 \\
\hline 廊坊市 & 7 & 滨州市 & 6 \\
\hline 石家庄市 & 10 & 德州市 & 11 \\
\hline 唐山市 & 4 & 东营市 & 3 \\
\hline 邢台市 & 13 & 荷泽市 & 9 \\
\hline 江苏省 & 14 & 济南市 & 2 \\
\hline 连云港市 & 3 & 济宁市 & 8 \\
\hline 宿迁市 & 4 & 聊城市 & 8 \\
\hline 徐州市 & 7 & 临沂市 & 1 \\
\hline- & - & 泰安市 & 1 \\
\hline - & - & 淄博市 & 1 \\
\hline
\end{tabular}

分析 1990-2015年期间农村居民点用地的空间分布 及变化特征。其中, 1990 年和 2015 年两期农村居 民点数据是利用下载自美国地质调查局网站 (http://glovis.usgs.gov/) 的 Landsat 4-5 和 Landsat 8 遥感影像解译获得。需要指出的是, 由于黄淮海平 原范围较大,遥感影像质量不均一等问题,部分地 区 1990 年或 2015 年的遥感影像可能由于含云量较 高等原因导致质量较低而无法利用,则需采用相邻 年份的遥感影像代替。最终用于解译 1990 年和 2015 年黄淮海平原农村居民点的遥感影像分别有 32 景和 27 景 $($ 表 2)。此外,本文还收集了中国电子 地图数据以辅助提取农村居民点,并从区域经济统 计年鉴和相关省市统计年鉴中收集了黄淮海平原 240 个县级行政单元的乡村人口数据, 用于后续的 人均农村居民点面积的计算。
表 2 用于解译 1990 年和 2015 年农村居民点的遥感影像

Table 2 The images used in the interpretation of rural settlement in 1990 and 2015

\begin{tabular}{cc}
\hline 1990年所使用数据数据标识 & 2015年所使用数据数据标识 \\
\hline LT51200361991243BJC00 & LC81200362013239LGN00 \\
LT51210331991234HAJ00 & LC81200362015133LGN00 \\
LT51210341991266BJC00 & LC81210342014201LGN00 \\
LT51210341992237BJC01 & LC81210362014121LGN00 \\
LT51210361987223BJC00 & LC81210372013214LGN00 \\
LT51210371987223BJC00 & LC81210372014121LGN00 \\
LT51210371995245CLT00 & LC81230322014231LGN00 \\
LT51220331990254HAJ00 & LC81220322014224LGN00 \\
LT51220331992212HAJ01 & LC81220342013205LGN00 \\
LT51220341992292BJC00 & LC81220352013205LGN00 \\
LT51220351987262BJC00 & LC81220352013237LGN00 \\
LT51220361987262BJC00 & LC81220362013205LGN00 \\
LT51220371987262BJC00 & LC81220372013205LGN00 \\
LT51220371992292BJC00 & LC81220372013221LGN00 \\
LT51230321992251BJC01 & LC81220372015211LGN00 \\
LT51230331987237BJC00 & LC81230332014231LGN00 \\
LT51230331991232HAJ00 & LC81230342015250LGN00 \\
LT51230331992251BJC01 & LC81230352015250LGN00 \\
LT51230341990245BJC00 & LC81230362013228LGN00 \\
LT51230351990245BJC00 & LC81230362015250LGN00 \\
LT51230361990245BJC00 & LC81230372015234LGN00 \\
LT51230361994224BJC00 & LC81240332014222LGN00 \\
LT51230361996230CLT00 & LC81240342015225LGN00 \\
LT51230371990245BJC00 & LC81240352014222LGN00 \\
LT51230371994224BJC00 & LC81240362013219LGN00 \\
LT51230381994224BJC00 & LC81240362014206LGN00 \\
LT51240331987212BJC00 & LC81240362015257LGN00 \\
LT51240341987212BJC00 & \\
LT51240351992210BJC01 & \\
\hline
\end{tabular}

\section{3 研究方法}

\section{1 农村居民点解译}

黄淮海平原范围较大,覆盖整个研究区需要多 景遥感影像。一方面, 不同景遥感影像之间,甚至 同景影像内均存在较大差异; 另一方面,多景影像 合并后,数据量过大。因此,进行分景解译。

遥感影像的质量对于解译精度和解译的工作 量均有较大影响,应尽量选择含云量低、地类之间 区分度较好的影像。对于本文的研究区而言, 7、8 月份时农村居民点与其他地类之间的区分度较高， 
是较为理想的选择。此外, 为了提高工作效率和解 译精度,还应根据影像质量和县域行政单元范围, 合理裁切遥感影像用于后续解译工作。

获得较为理想的遥感影像之后, 本文采用 eCognition developer 8.9 软件进行黄淮海平原 1990 年和 2015 年两期农村居民点数据的解译工作。具 体解译工作主要包括两大过程: 基于 eCognition developer 8.9 的农村居民点自动解译和基于 ArcGIS10.0 的解译后修改。其中, 在基于 eCognition developer 8.9 的农村居民点自动解译过程中, 首先 需要对遥感影像进行分割, 而分割系数的设置尤为 关键,这将会影响到解译的精度和后续修改的工作 量。在经过多次试验对比之后发现,对于 Landsat 8 遥感影像, 分割系数设为 $125 \sim 130$ 之间时, 解译效果 较理想; 而适合于 Landsat 4-5 遥感影像的分割系数 则在12 15之间。

经过以上步骤之后, 可获得农村居民点解译的 初步结果。在此基础上,通过属性选择可以提取城 乡居民点用地。然后, 利用中国电子地图中城镇点 位置空间分布可以将城镇居民点和农村居民点用 地数据进一步分离, 从而获得农村居民点空间分布 数据。基于 ArcGIS10.0 的解译后修改阶段最耗时 耗力, 但也是农村居民点解译必不可少的工作。解 译后修改的基本原则是, 以遥感影像为准修改初步 解译结果。最后,利用谷歌地球影像对 2015 年的解 译结果进行验证,总体精度在 $95 \%$ 以上。

\section{2 基于空间叠加的农村居民点类型划分}

本文采用空间叠加的方法进行农村居民点类 型划分, 避免了综合评价法等方法的主观性和随意 性,并且不会掩盖农村居民点在各个维度特征上的 差异性。主要包括专题图的制作和空间叠加两个 步骤。

在 ArcGIS10.0 中制作农村居民点空间布局专 题图的流程如图 2 所示。首先, 基于遥感解译获得 的农村居民点用地空间信息, 在 ArcGIS10.0 中计算 各农村居民点斑块的面积和形状指数 (斑块的周长 与面积之比); 然后利用 Feather to point 功能将农村 居民点面图层转为带有面积和形状指数属性的点 图层; 在此基础上,利用空间统计功能统计县域内 农村居民点的平均斑块面积和形状指数,并计算县

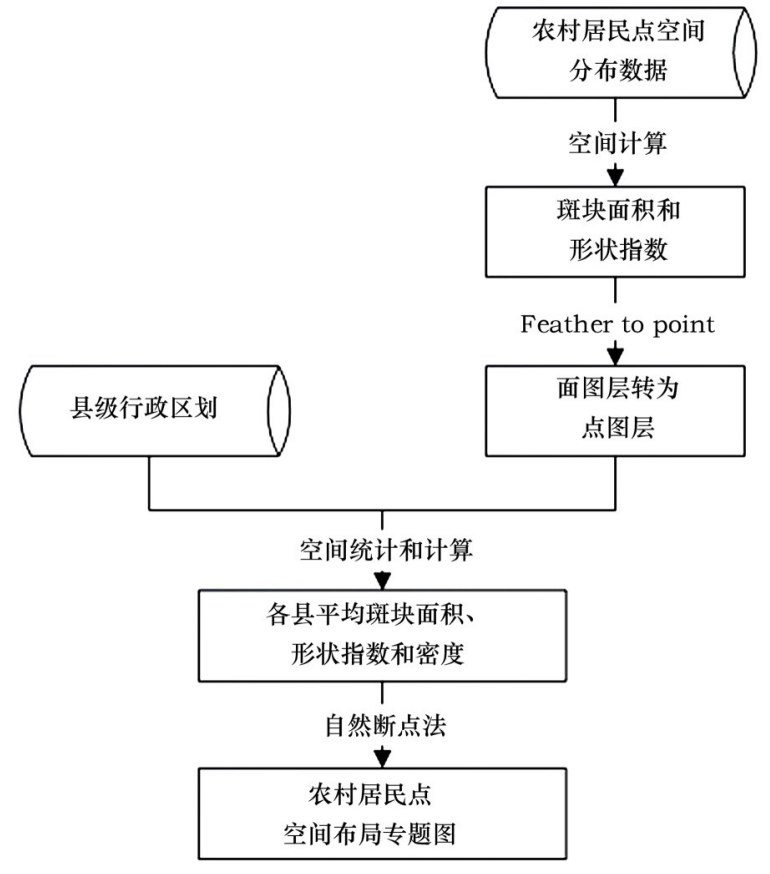

图 2 农村居民点空间布局专题图制作流程

Figure 2 The process of generating the distribution thematic map of rural settlement

域内农村居民点密度; 最后, 采用自然断点法将农 村居民点的平均斑块面积分为大斑块、中斑块和小 斑块三级,将形状指数分为不规整和较规整两级, 将密度分为高密度、中密度和低密度三级,制作农 村居民点规模、形状和密度空间分布专题图。以上 过程均是在 ArcGIS10.0 中完成。需要说明的是, 相 比中国其他地区的农村居民点, 黄淮海平原农村居 民点的规模较大, 密度较高 ${ }^{[3]}$, 这里的分级大小是对 于黄淮海平原内部农村居民点用地而言, 是一种相 对的分级。

将以上农村居民点空间分布专题图进行空间 叠加, 并根据农村居民点规模、形态和分布的不同 组合特征划分农村居民点类型。

\section{4 结果与分析}

\section{1 农村居民点特征}

1990-2015 年期间, 黄淮海平原农村居民点变 变的主要特征为数量增多,平均斑块面积和总面积 扩大、农村居民点总面积占黄淮海平原总面积的比 例 (面积占比)升高、密度增大等;2015 年黄淮海平 原农村居民点的空间分布主要表现为数量多、平均 斑块面积和总面积大、面积占比和密度较高等特 
征。具体而言, 农村居民点用地斑块数量、平均斑 块面积、总面积、面积占比和密度分别由 1990 年的 138459 个, $0.17 \mathrm{~km}^{2}, 24401.09 \mathrm{~km}^{2}, 9.59 \%, 0.54$ 个/ $\mathrm{km}^{2}$ 增加至 2015 年的 144941 个, $0.18 \mathrm{~km}^{2}, 26214.23$ $\mathrm{km}^{2}, 10.30 \%, 0.57$ 个 $/ \mathrm{km}^{2}$ 。

为了进行农村居民点类型的划分, 首先在县域 尺度上分析了黄淮海平原 2015 年农村居民点用地 的规模、形状和密度特征。

\subsection{1 规模特征}

黄淮海平原县域内农村居民点平均斑块面积 介于 $0.04 \sim 0.73 \mathrm{~km}^{2}$ 之间（图 3)。135 个县域内农村 居民点的平均斑块面积小于 $0.22 \mathrm{~km}^{2}$, 根据农村居 民点规模的划分标准 (表 3 ), 为小斑块级别。该类 型农村居民点用地总面积为 $17684.30 \mathrm{~km}^{2}$, 占黄淮 海平原农村居民点用地总面积的比例高达 $67.46 \%$ (表 3)。包括黄河以南的大部分县域、黄河以北山 东省的大部分县域和河北省衡水市的大部分县 域。大斑块类型的县域仅有 21 个,该类型农村居民

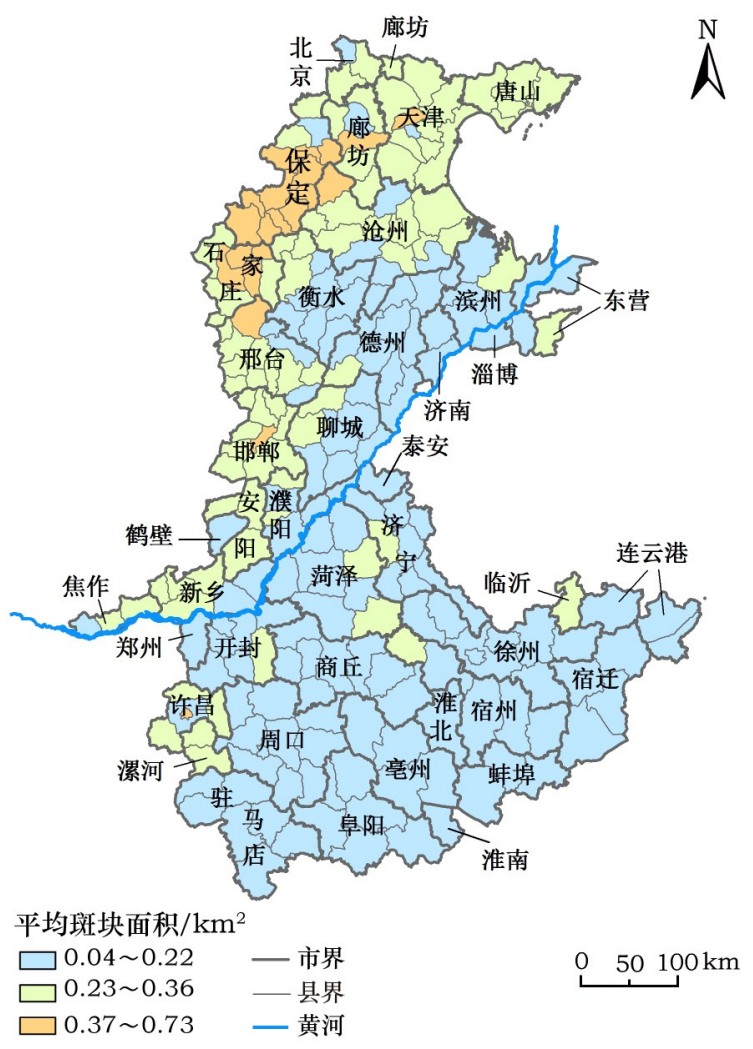

图 3 县域尺度农村居民点平均斑块面积的空间分布

Figure 3 The spatial distribution of the mean patch area of rural settlement at county level
表 3 农村居民点用地划分标准与各等级农村居民点 用地总面积、比例

Table 3 The classification standard of rural settlement and

the total area and proportion of rural settlement for each class

\begin{tabular}{ccccc}
\hline \multirow{2}{*}{ 维度 } & 级别 & $\begin{array}{c}\text { 范围 } \\
/\left(\mathrm{km}^{2}, \text { 个 } / \mathrm{km}^{2}\right)\end{array}$ & $\begin{array}{c}\text { 总面积 } \\
/ \mathrm{km}^{2}\end{array}$ & $\begin{array}{c}\text { 比例 } \\
/ \%\end{array}$ \\
\hline 规模 & 大斑块 & $0.37 \sim 0.73$ & 1469.62 & 5.61 \\
& 中斑块 & $0.23 \sim 0.36$ & 7060.31 & 26.93 \\
& 小玟块 & $0.04 \sim 0.22$ & 17684.30 & 67.46 \\
形状 & 不规整 & $1.71 \sim 2.07$ & 10078.45 & 38.45 \\
& 较规整 & $1.28 \sim 1.70$ & 16135.79 & 61.55 \\
分布 & 高密度 & $0.72 \sim 1.11$ & 9426.46 & 35.96 \\
& 中密度 & $0.43 \sim 0.71$ & 9551.98 & 36.44 \\
& 低密度 & $0.00 \sim 0.42$ & 7235.79 & 27.60 \\
\hline
\end{tabular}

点用地总面积仅为 $1469.62 \mathrm{~km}^{2}$, 占黄淮海平原农村 居民点用地总面积的比例也仅为 $5.61 \%$ 。主要集中 分布在黄淮海平原西北部的河北省保定市和石家 庄市境内。其余中斑块县域农村居民点平均斑块 面积介于 $0.23 \sim 0.36 \mathrm{~km}^{2}$ 之间, 总面积为 $7060.31 \mathrm{~km}^{2}$, 主要分布在大斑块类型县域和小斑块类型县域之 间的过渡区域。

\subsection{2 形状特征}

黄淮海平原农村居民点形状指数介于 1.28 2.07 之间。根据形状指数的分级结果, 不规整类型 的县域数量相对较少,共有 100 个,农村居民点总面 积占黄淮海平原农村居民点总面积的比例也相对 较低,为 $38.45 \%$ (表 3)。主要分布在京津冀交界处、 河北省邢台市和甘郸市大部分县域和苏皖交界处 大部分地区 (表 3 , 图 4)。而其余 140 个县域的农村 居民点形状指数均在 $1.28 \sim 1.70$ 之间,属于形状较规 整级别。

\subsection{3 密度特征}

黄淮海平原农村居民点密度的空间分布差异 明显,呈现出显著的集聚格局。其中,农村居民点 密度小于 0.42 个 $/ \mathrm{km}^{2}$ 的县域主要分布在黄淮海平 原北部和西部;而鲁豫皖交界处的大部分县域农村 居民点密度较大,介于 $(0.72 \sim 1.11)$ 个 $/ \mathrm{km}^{2}$, 为高密度 级别; 其余县域农村居民点密度则介于 $(0.43 \sim 0.71)$ 个 $/ \mathrm{km}^{2}$ 之间, 为中密度级别 (表 3, 图 5)。此外, 高密 度和中密度类型农村居民点用地占黄淮海平原农 村居民点用地总面积的比例相当,分别为 $35.96 \%$ 和 $36.44 \%$, 低密度类型农村居民点用地的比例相对较 


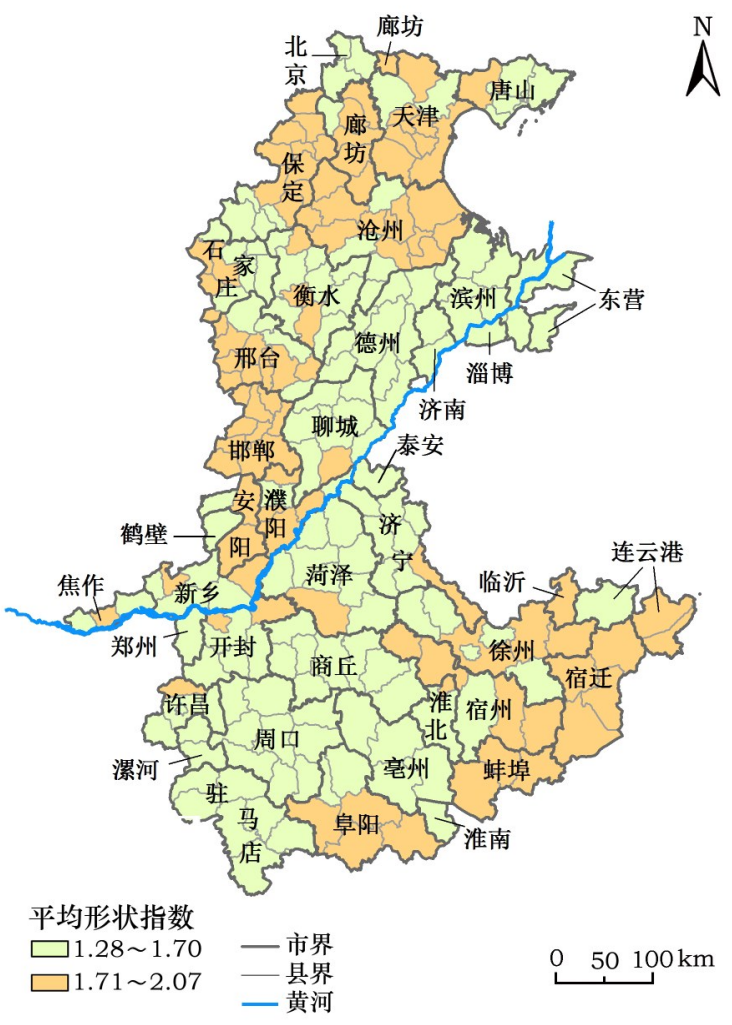

图 4 县域尺度农村居民点形状指数的空间分布

Figure 4 The spatial distribution of the mean shape index of rural settlement at county level

低,为 $27.60 \%$ (表 3$)$ 。

\section{2 不同类型农村居民点的差异性分析}

\subsection{1 数量与分布的差异性}

本研究将黄淮海平原农村居民点划分为 12 类 （表 4,图 6)。其中,小斑块较规整高密度、小斑块 较规整中密度和中斑块不规整低密度三种类型县 域数量多,面积占比大, 分布广, 是黄淮海平原的主 要分布类型。三种类型的县域数量分别为 42 个, 44 个和 44 个; 县域内农村居民点总面积占黄淮海 平原农村居民点总面积的比例分别为 $26.80 \%$ 、 $17.06 \%$ 和 $11.67 \%$ (表 4$)$ 。其中, 小斑块较规整高密 度类型县域主要分布在河南商丘市、周口市、驻马 店市,安徽毫州市、淮北市和淮南市。小斑块较规 整中密度类型的县域则主要集中在更加偏北的山 东境内和河北沧州市南部、衡水市东部。河北邯郸 市、邢台市和沧州市, 天津市则是中斑块不规整低 密度类型县域的主要聚集区。

小斑块不规整中密度、小斑块不规整高密度和 大斑块不规整低密度三种类型县域分布也较为集

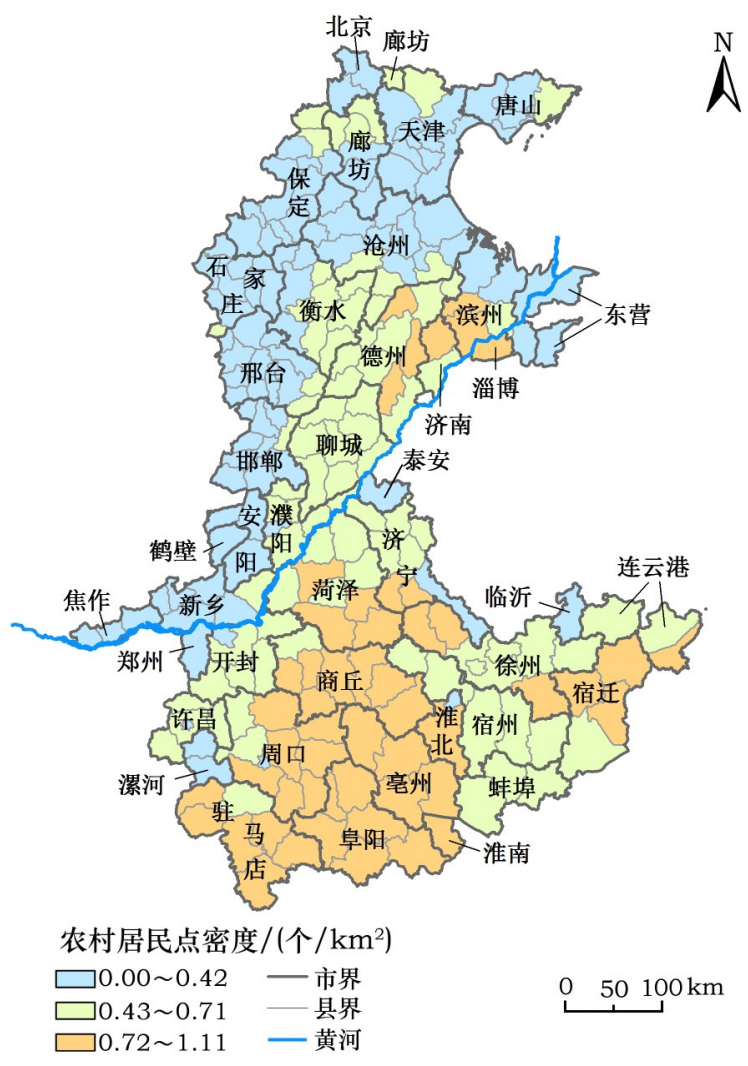

图 5 县域尺度农村居民点密度的空间分布

Figure 5 The spatial distribution of the density of rural settlement at county level

表 4 不同类型农村居民点的县域数量和面积占比

Table 4 The comparison of the number and area among different types of rural settlement

\begin{tabular}{crrc}
\hline 类型 & $\begin{array}{c}\text { 县域数量 } \\
\text { 个个 }\end{array}$ & $\begin{array}{c}\text { 农村居民点 } \\
\text { 总面积/km² }\end{array}$ & $\begin{array}{c}\text { 占黄淮海平原农 } \\
\text { 村居民点总面积 } \\
\text { 的比例/\% }\end{array}$ \\
\hline 大斑块不规整低密度 & 12 & 884.39 & 3.37 \\
大斑块较规整低密度 & 9 & 585.23 & 2.23 \\
小斑块不规整低密度 & 4 & 105.65 & 0.40 \\
小斑块不规整高密度 & 9 & 2135.30 & 8.15 \\
小斑块不规整中密度 & 21 & 2998.88 & 11.44 \\
小斑块较规整低密度 & 15 & 946.73 & 3.61 \\
小斑块较规整高密度 & 42 & 7024.70 & 26.80 \\
小斑块较规整中密度 & 44 & 4473.04 & 17.06 \\
中斑块不规整低密度 & 44 & 3058.70 & 11.67 \\
中斑块不规整中密度 & 10 & 895.53 & 3.42 \\
中斑块较规整低密度 & 19 & 1655.09 & 6.31 \\
中斑块较规整中密度 & 11 & 1450.99 & 5.54 \\
\hline
\end{tabular}

中。小斑块不规整中密度和小斑块不规整高密度 两种类型的县域主要分布在黄淮海平原南部地区, 大玟块不规整低密度类型县域则聚集在黄淮海平 


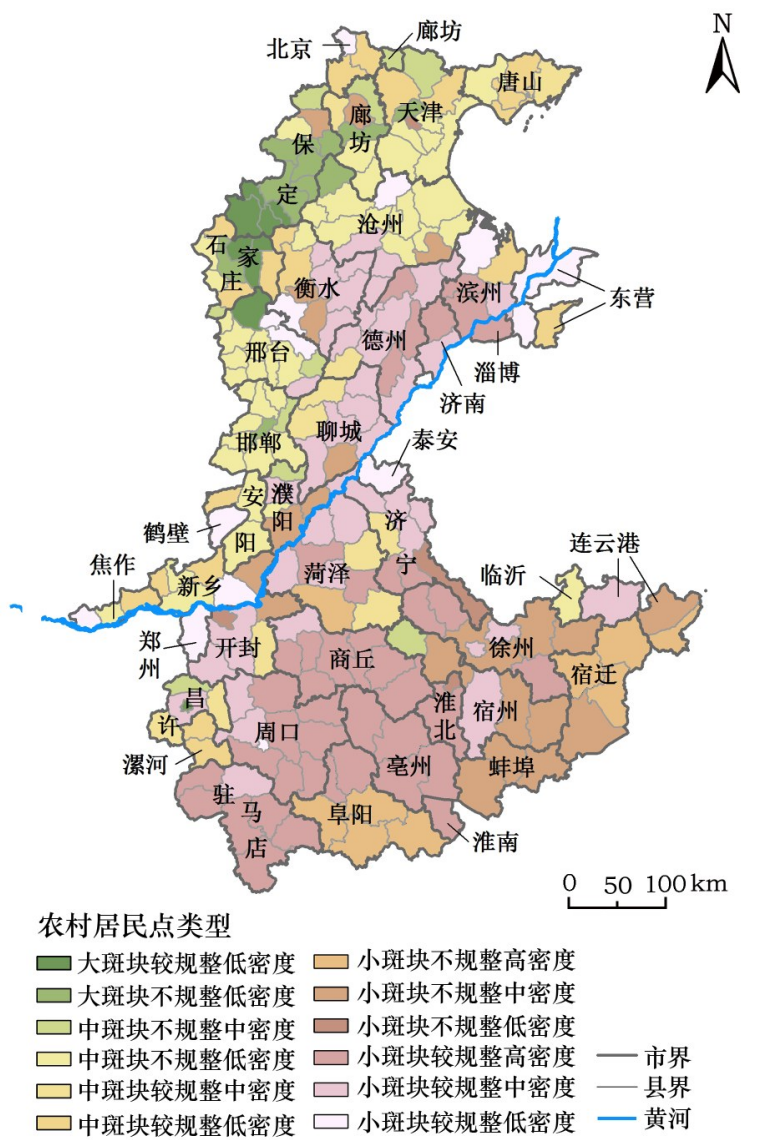

图6 不同类型农村居民点的空间分布

Figure 6 The spatial distribution of different types of rural settlement

原北部。其中,小斑块不规整中密度类型的县域主 要分布在安徽蛙埠市、宿迁市和江苏徐州市; 小斑 块不规整高密度类型县域则在安徽阜阳市和江苏 宿迁市较为集中; 河北保定市是大斑块不规整低密 度类型县域的集中区。

尽管中斑块较规整低密度和小斑块较规整低 密度两种类型县域数量也较多,分别有 19 和 15 个, 但其分布较为分散; 而其他类型县域不仅数量较 少,分布也较为分散。

\subsection{2 人均农村居民点用地面积的差异性}

中斑块不规整中密度、中斑块较规整中密度、 小斑块不规整中密度和小斑块较规整高密度等类 型县域内人均农村居民点面积较高, 分别为 $199.65 \mathrm{~m}^{2} 、 198.98 \mathrm{~m}^{2} 、 193.97 \mathrm{~m}^{2}$ 和 $192.68 \mathrm{~m}^{2}$, 主要分布 在黄淮海平原黄河以南的豫皖苏交界处 (表 5,图 6)。由于气候条件和风俗习惯等原因,该区域农村 居民点内部“田间种房”的现象普遍(图 7a), 即农户
表 5 不同类型农村居民点的人均面积、数量变化 和面积变化差异

Table 5 The differences among different types of rural settlement

\begin{tabular}{lccc} 
类型 & $\begin{array}{c}\text { 人均农村居 } \\
\text { 民点面积 } / \mathrm{m}^{2}\end{array}$ & $\begin{array}{c}\text { 农村居民数量变化 } / \text { 个 } \\
\text { 大面积变化 } / \mathrm{km}^{2}\end{array}$ \\
\hline 大斑块不规整低密度 & 175.06 & -20 & 19.02 \\
大斑块较规整低密度 & 160.57 & -21 & 11.08 \\
小斑块不规整低密度 & 63.01 & 1 & 2.36 \\
小斑块不规整高密度 & 184.85 & 99 & 24.77 \\
小斑块不规整中密度 & 193.97 & 135 & 23.89 \\
小斑块较规整低密度 & 185.65 & 38 & -5.12 \\
小斑块较规整高密度 & 192.68 & 42 & 14.15 \\
小斑块较规整中密度 & 180.57 & 31 & -12.11 \\
中斑块不规整低密度 & 166.02 & 6 & 5.83 \\
中斑块不规整中密度 & 199.65 & 7 & 9.06 \\
中斑块较规整低密度 & 189.16 & 6 & 11.03 \\
中斑块较规整中密度 & 198.98 & -17 & 15.14 \\
\hline
\end{tabular}

住宅多以单栋独户的形式存在,农户住宅之间间距 较大, 连接性较差, 分布较为分散, 用地较为粗放, 同时也加大了基础设施和公共服务设施等的配置 成本; 提升建设用地比例, 优化农村居民点内部结 构是该区域农村居民点优化调整的重点。

大斑块不规整低密度、大斑块较规整低密度、 中斑块不规整低密度和小斑块不规整低密度等类 型县域内人均农村居民点面积较低, 分别为 $175.06 \mathrm{~m}^{2} 、 160.57 \mathrm{~m}^{2} 、 166.02 \mathrm{~m}^{2}$ 和 $63.01 \mathrm{~m}^{2}$, 主要集聚 在河北除衡水市之外的大部分地区和天津市境内, 该区域内新农村建设、规划管理等落实较好,住宅 规模往往遵循相应的建设标准,住宅风格形式较为 统一, 相邻住户通常共用山墙, 几户组成一排, 排间 距较合理, 成排有序规则分布, 农村居民点内部建 设用地利用率较高(图 7b)。并且农户居住集聚程 度较高, 耕作半径相对较大, 使得该区域农村居民 点密度相对较低。

综上可以看出, 相比农村居民点的形状,农村 居民点的规模和密度对人均农村居民点面积的影 响较大; 人均农村居民点面积较高的县域, 多是中 小斑块和中高密度的组合; 而农村居民点规模较 大、密度较低的组合下，人均农村居民点面积较 低。这表明在小而密集的分布状态下,农村居民点 用地更加粗放; 而在规模较大、密度较低的分布状 态下, 农村居民点用地更加集约。 


\section{a.农户住宅分散布局典型影像}

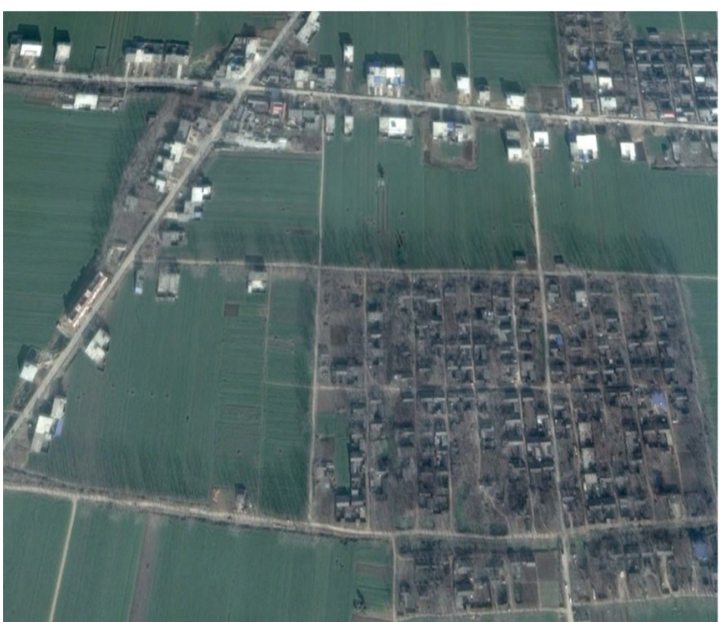

\section{b.农户住宅紧凑型典型影像}

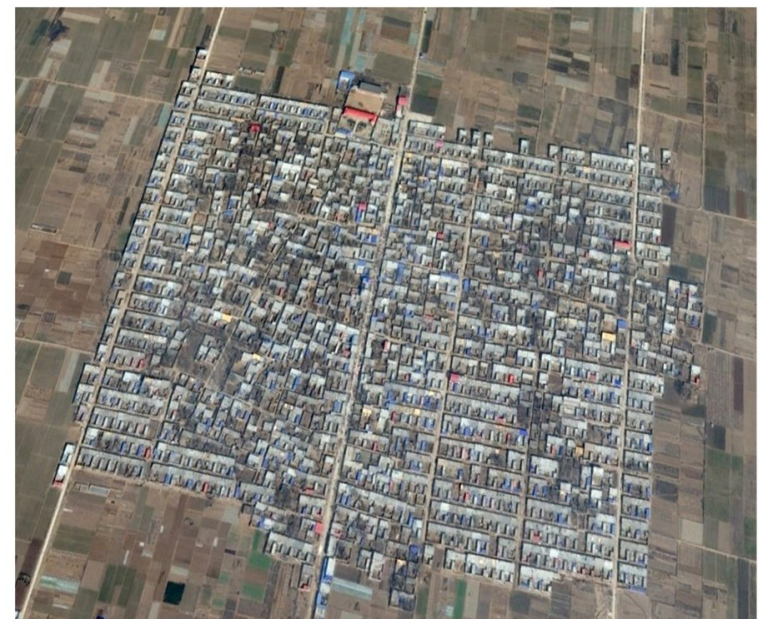

图 7 农户住宅分散布局和紧凑布局典型影像

Figure 7 The scattered and compact distribution of rural residence

4.2.3 农村居民点用地变化的差异性

从农村居民点数量变化差异来看, 大部分类型 农村居民点数量呈增加趋势, 尤其是小斑块不规整 高密度、小斑块不规整中密度、小斑块较规整低密 度、小玟块较规整高密度和小玟块较规整中密度类 型县域内农村居民点数量增加较多, 分别为 99 个、 135 个、 38 个、 42 个和 31 个, 主要分布在黄河以南的 大部分地区以及黄河以北的山东境内和河北衡水 市境内(表 5, 图 6)。农村居民点沿路新建是导致农 村居民点数量增加的主要原因之一, 尤其是在安徽 境内。例如, 对比图 $8 \mathrm{a}$ 和图 $8 \mathrm{~b}$ 可以发现, 相比 2004
年, 2015 年道路两边新建了许多农村居民点。仅大 斑块不规整低密度、大斑块较规整低密度和中斑块 较规整中密度三种类型县域内农村居民点数量呈 现出减少趋势, 县域减少数量分别为 20 个、 21 个和 17 个, 在河北保定市及周边县域较为集中, 农村居 民点扩张导致相邻农村居民点斑块连接合并和城 镇扩张占用是导致该区域农村居民点数量减少的 主要原因; 其他类型农村居民点数量变化不明显。

综上所述,农村居民点的数量变化与农村居民 点的规模和密度的关系较为紧密。农村居民点数 量增加较多的县域类型, 多为小斑块与中高密度的 a.2004年

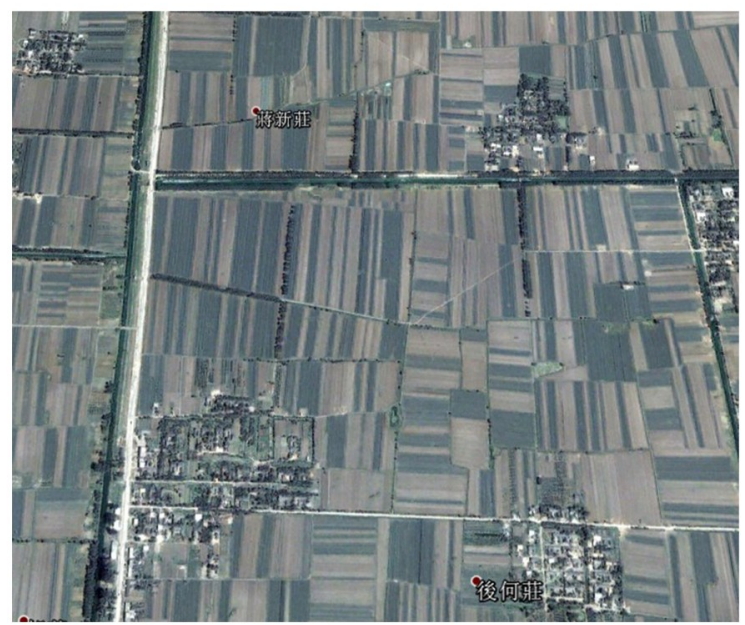

b.2015年

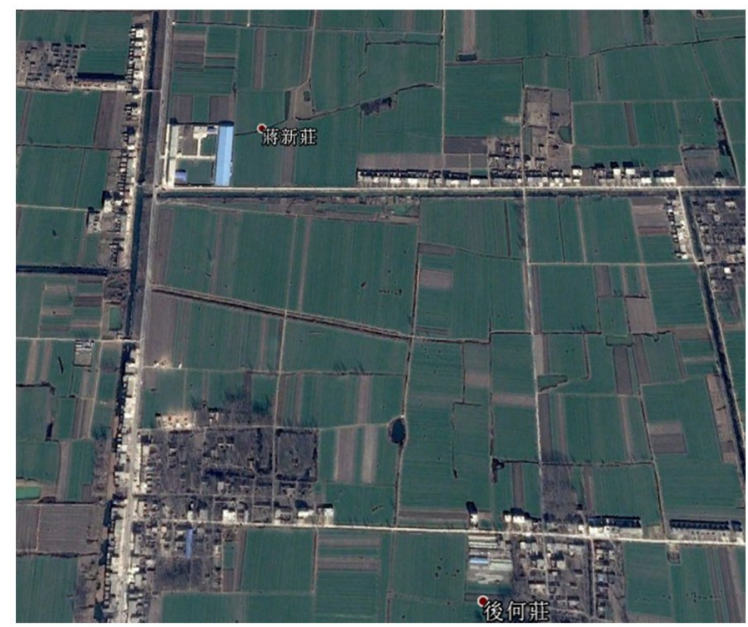

图 8 农村居民点沿路扩张典型影像

Figure 8 The expansion of rural settlement along the road 
组合; 而农村居民点数量呈减少趋势的县域类型, 多为中大斑块与中低密度的组合。

从农村居民点面积变化差异来看 (表 5 ), 类似 农村居民点数量变化特征, 大部分类型县域内农村 居民点面积均呈增加趋势。尤其是大斑块不规整 低密度、小斑块不规整高密度、小斑块不规整中密 度三种类型县域内农村居民点面积增加较为显著, 增加面积分别为 $19.02 \mathrm{~km}^{2} 、 24.77 \mathrm{~km}^{2} 、 23.89 \mathrm{~km}^{2}$, 大 部分聚集在黄河以南的地区,如安徽阜阳市、蚌埠 市、宿州市和江苏宿迁市、徐州市等, 黄河以北仅在 河北保定市相对较为集中(表 5,图 6)。这些农村居 民点面积增加较显著的县域类型, 大多是形状不规 整与大斑块或小斑块的组合。主要是因为该区域 农村居民点的扩张以边缘扩张模式为主导 ${ }^{[20]}$,这使 得其形状多为不规则形。农村居民点面积呈现出 减少趋势的县域类型为小斑块较规整低密度、小斑 块较规整高密度、小斑块较规整中密度等, 减少面 积分别为 $5.12 \mathrm{~km}^{2} 、 14.15 \mathrm{~km}^{2} 、 12.11 \mathrm{~km}^{2}$ 。包括黄河 以南的大部分县域以及黄河以北山东境内的大部 分县域和河北衡水市的大部分县域,普遍存在农村 居民点规模较偏小的特征。此外,新农村建设对该 区域影响较大,经迁村并点、新村安置等,新建农村 一般形态较规则, 尽管初具规模, 但相比黄淮海平 原北部农村居民点, 其规模仍较小。因此,农村居 民点面积减少的县域类型均为形状较规整和小斑 块的组合。

综上所述, 相比农村居民点的密度, 农村居民 点的规模和形状与农村居民点面积变化之间的关 系更为密切; 农村居民点面积增加显著的县域多为 形状不规则型,而农村居民点面积减少主要发生在 形状较规整和小斑块的组合类型中。

\section{5 结论}

本文基于遥感解译的农村居民点数据,在分析 农村居民点空间分布特征的基础上,采用空间叠加 的方法划分了 2015 年农村居民点类型,并对不同类 型农村居民点的差异性进行了深人分析。

结果表明 2015 年黄淮海平原县域内农村居民 点平均斑块面积介于 $0.04 \sim 0.73 \mathrm{~km}^{2}$ 之间, 形状指数 介于 $1.28 \sim 2.07$ 之间, 密度在 $(0.00 \sim 1.11)$ 个 $/ \mathrm{km}^{2}$ 之 间。黄淮海平原农村居民点可划分为 12 种类型, 并
以小玟块较规整高密度、小斑块较规整中密度和中 斑块不规整低密度三种类型为主导。从空间分布 上来看, 相比于黄河以南地区, 黄淮海平原黄河以 北的县域内农村居民点斑块规模较大、密度较低。 具体而言, 小斑块较规整高密度类型县域主要分布 在河南商丘市、周口市、驻马店市, 以及安徽毫州 市、淮北市和淮南市。小斑块较规整中密度类型的 县域则主要集中在更加偏北的山东境内与河北沧 州市南部、衡水市东部。河北邯䣋市、邢台市和沧 州市以及天津市则是中斑块不规整低密度类型县 域的主要聚集区。小斑块不规整中密度类型的县 域主要分布在安徽蚌埠市、宿迁市和江苏徐州市; 小玟块不规整高密度则在安徽阜阳市和江苏宿迁 市较为集中;河北保定市是大斑块不规整低密度类 型县域的集中区。其他类型县域分布较为分散。

不同类型之间农村居民点的比较结果表明：

(1)农村居民点的规模和密度对人均农村居民 点面积的影响较大。斑块较小, 密度较高的情况下 更容易导致农村居民点人均面积偏高,用地粗放; 而斑块较大、密度较低的组合下人均农村居民点面 积多较低,用地较为集约。

(2)农村居民点数量增加较多的县域,多为小 斑块与其他特征的组合类型;而农村居民点数量呈 减少趋势的县域,多为中大斑块与中低密度的组合 类型。

（3)农村居民点的规模和形状与农村居民点面 积变化之间的关系较为密切;形状不规整和小斑块 的组合下农村居民点面积增加更加显著,而农村居 民点面积减少主要发生在形状较规整和小斑块的 组合类型中。

\section{参考文献(References):}

[1] 马晓冬,李全林,沈一. 江苏省乡村聚落的形态分异及地域类 型[J]. 地理学报,2012,67(4):516-525. [Ma X D, Li Q L, Shen Y. Morphological difference and regional types of rural settlements in Jiangsu Province[J]. Acta Geographica Sinica, 2012, $67(4): 516-525$.]

[2] Zhu F K, Zhang F R, Li C, et al. Functional transition of the rural settlement: Analysis of land-use differentiation in a transect of Beijing, China[J]. Habitat International, 2014, 41 (1) : 262- 
271.

[3] Tian G J, Qiao Z, Zhang Y Q. The investigation of relationship between rural settlement density, size, spatial distribution and its geophysical parameters of China using Landsat TM images[J]. Ecological Modelling, 2012,231(4):25-36.

[4] 蔡为民,唐华俊,陈佑启,等. 近 20 年黄河三角洲典型地区农村 居民点景观格局 [J]. 资源科学, 2004,26(5):89-97. [Cai W M, Tang H J, Chen Y Q, et al. Landscape pattern of rural residential areas in Yellow River Delta in recent 20 years[J]. Resources Science, 2004,26(5): 89-97.]

[5]鄂施璇,雷国平, 宋戈. 松嫩平原粮食主产区农村居民点格局 及影响因素分析 [J]. 农业工程学报, 2016,32(18):234-240. [E S X, Lei G P, Song G. Analysis on pattern and influence factors of rural settlements in grain main production area of Songnen Plain[J]. Transactions of the Chinese Society of Agricultural Engineering,2016,32(18):234-240.]

[6] 焦贝贝,石培基,刘春芳,等. 黄土高原低山丘陵区农村居民点 分布与地形因子关系研究-以兰州市七里河区为例 $[\mathrm{J}]$. 资源科 学, 2013,35(8) : 1719-1727. [Jiao B B, Shi P J, Liu C F, et al. The distribution of rural settlements in relation to land form factors in low hilly land on the loess plateau[J]. Resources Science, 2013,35(8):1719-1727.]

[7]邹利林,王占岐,王建英. 山区农村居民点空间布局与优化 [J]. 中国土地科学, 2012,26(9): 71-77. [Zou L L, Wang Z Q, Wang J Y. Spatial distribution and optimization of rural residential land in the mountainous area[J]. China Land Sciences, 2012,26(9): 71-77.]

[8] 李红波,张小林,吴启焰,等. 发达地区乡村聚落空间重构的特 征与机理研究-以苏南为例 $[J]$. 自然资源学报, 2015, (4):591603. [Li H B, Zhang X L, Wu Q Y, et al. Characteristics and mechanism of rural settlements spatial reconstruction in developed aeas- a case study of southern Jiangsu[J]. Journal of Natural Resources, 2015, (4):591-603.]

[9]任国平,刘黎明,付永虎,等. 都市郊区乡村聚落景观格局特征 及影响因素分析 [J]. 农业工程学报, 2016,32(2):220-229. [Ren G P, Liu L M, Fu Y H, et al. Analysis of characteristic and influencing factors of rural settlement landscape pattern in metropolitan suburbs[J]. Transactions of the Chinese Society of Agricultural Engineering, 2016,32(2):220-229.]

[10] 曲衍波, 张凤荣, 郭力娜, 等. 京郊不同城市功能区农村居民点 用地集约度的比较研究 [J]. 资源科学, 2011,33(4):720-728。 [Qu Y B, Zhang F R, Guo L N, et al. Comparison of the use intensity of rural residential land in different urban functional areas in the suburbs of Beijing[J]. Resources Science, 2011, 33
(4) :720-728.]

[11] 林超. 聚落分类之讨论 [J]. 地理, 1938, 6(1) : 17-18. [Lin C. The discussion of settlement classification[J]. Geography, 1938, 6(1) : 17-18.]

[12] 马少春. 环洱海地区乡村聚落系统的演变与优化研究 [D]. 开 封: 河南大学, 2013. [Ma S C. Study on Evolution and Optimization of Rural Settlement System of Area Surrounding Erhai Lake[D]. Kaifeng: University of Henan, 2013.]

[13］谭雪兰. 农村居民点空间布局演变研究[D]. 长沙: 湖南农业大 学, 2011. [Tan X L. Study on Space Distribution Evolution of Rural Settlement[D]. Changsha: Hunan Agriculture University, 2011.]

[14] Long H L, Zou J, Liu Y S. Differentiation of rural developmen driven by industrialization and urbanization in eastern coastal China[J]. Habitat International, 2009,33(4):454-462.

[15] 乔陆印,刘彦随,杨忍. 中国农村居民点用地变化类型及调控 策略[J]. 农业工程学报, 2015,31(7): 1-8. [Qiao L Y,Liu Y S, Yang R. Regional types and regulating stategy of changes for rural residential land in China[J]. Transactions of the Chinese Society of Agricultural Engineering, 2015,31(7): 1-8.]

[16] Song W, Chen B M, Zhang Y. Land use regionalization of rural settlements in China[J]. Chinese Geographical Science, 2013,23 (4) :421-434

[17] 姜广辉,何新,马雯秋,等. 基于空间自相关的农村居民点空间 格局演变及其分区[J]. 农业工程学报,2015,31(13):265-273. [Jiang G H, He X, Ma W Q, et al. Rural settlements spatial pattern evolution and zoning district based on spatial autocorrelation[J]. Transactions of the Chinese Society of Agricultural Engineering, 2015,31(13):265-273.]

[18] 张瑞娟,姜广辉,王明珠, 等. 基于多维特征组合的农村居民点 布局分类[J]. 农业工程学报,2015,31(4):286-292. [Zhang R J, Jiang G H, Wang M Z, et al. Layout classification of rural settlement based on combination of multi- dimensional characteristics[J]. Transactions of the Chinese Society of Agricultural Engineering,2015,31(4):286-292.]

[19] 田光进,刘纪远,庄大方. 近 10 年来中国农村居民点用地时空 特征[J]. 地理学报, 2003,58(5): 651-658. [Tian G J, Liu J Y, Zhuang D F. The temporal- spatial charateristics of rural residential land in China in the 1990s[J]. Acta Geographica Sinica , 2003, 58 (5):651-658.]

[20] Tan M H, Li X B. The changing settlements in rural areas under urban pressure in China: Patterns, driving forces and policy implications[J]. Landscape \& Urban Planning, 2013, 120(6) : 170-177. 


\title{
The spatial distribution and evolution of different types of rural settlements on Huang-Huai-Hai Plain
}

\author{
DONG Guanglong ${ }^{1,2}$, XU Erqi ${ }^{1}$,ZHANG Hongqi ${ }^{1}$ \\ (1. Key Laboratory of Land Surface Pattern and Simulation, Institute of Geographic Sciences and Natural Resources Research, \\ Chinese Academy of Sciences, Beijing 100101, China; \\ 2. University of Chinese Academy of Sciences, Beijing 100049, China)
}

\begin{abstract}
Classifying types of rural settlements scientifically and identifying diversity among different types of rural settlements is the foundation of rural settlement management and the realization of rural settlement transformation development and new-type urbanization. Based on rural settlement data we classified rural settlement types using spatial overlay and compared its distinction. We found that there are 12 types of rural settlements on Huang-Huai-Hai Plain; the types little scale-relative regular- high density, little scale-relative regular-medium density and medium scale-irregular-low density are the three main types. The rural settlement in the north of the Yellow River on Huang-Huai- Hai Plain has a larger average patch area and lower density compared to those in the south. Compared to the shape of rural settlement, the scale and density of rural settlements show larger influence on rural settlement area per capita. The land use of rural settlement is more extensive with the combination of small scale and high density, while it is more intensive with the combination of large scale and low density. Most of the county shows increment in the number of small scale, while the type of relative large scale and relative low density declined. Compared to the density of rural settlements, the scale and shape of rural settlements have a closer relationship with the change in the area of rural settlements. The increment of rural settlement area is more obvious for irregular and small scale types, while reduction in area mainly happened in relative regular and small scale types.
\end{abstract}

Key words : rural settlement; spatial distribution; spatiotemporal evolution ; type; Huang-Huai-Hai Plain 